\title{
Pre and Post test Clinical study to evaluate the Immunomodulatory effect (IgE) of Virecana followed by Citrakaharitaki Leha in Allergic Asthma
}

\author{
Research Article
}

\section{Jyotish S Jayandan1*, James Chacko², Devipriya Soman³, Mahesh C Kundagol4}

\author{
1. PG Scholar, 2. Professor and Head, 3. Assistant Professor, 4. Associate Professor, \\ Department of Kayachikitsa, School of Ayurveda, Amrita Vishwa Vidyapeetham, \\ Vallikavu, Clappana P.O, Kollam, Kerala, India.
}

\begin{abstract}
Allergic Asthma is one among the diseases which imposes a great burden on the subjects by hampering the quality of life of patients, reducing productivity, and causing work absence. The literary search hinted that there are no published works reporting both clinical and immunological(IgE) outcomes in Allergic Asthma. So the present study was a pre and post test clinical study to evaluate the effect of Ayurvedic line of management in inducing both immunological(IgE) and clinical outcomes in Allergic Asthma. In this study 30 patients were administered classical Virecana Karma (drug induced purgation) followed by Shamanoushadi (internal medicine) for 30 days. Statistical Analysis was done using SPSS VER. 20. Wilcoxon signed rank test was used to evaluate the Subjective parameters, in order to interpret the time of significant change. For objective parameters Paired Samples t- Test was used to evaluate the difference of significant change. The results showed improvement in the subjective criteria, objective criteria and the overall effect of the therapy with the exception of no statistically significant results in immunomodulatory (IgE) effect which proves that the particular management protocol adopted is found to be clinically efficant but not effective in inducing changes at the immune level.
\end{abstract}

Key Words: Allergic Asthma, Ayurveda, Virecana, Citrakaharitaki Leha, Tamaka Svasa.

\section{Introduction}

In this modern era of increasing pollution rates and toxicity in everything that is used by the mankind there is an increasing rise of Allergic Disorders all over the world. The burden of Allergic diseases in India has been on an uprising trend in terms of prevalence as well as severity. Allergic diseases comprise of Asthma, Rhinitis, Anaphylaxis, Drug, Food, Insect allergy, Eczema, Urticaria and Angioedema. Approximately $20 \%$ to $30 \%$ of total population suffers from at least one of these Allergic diseases in India (1). Allergic Asthma is one among such diseases which imposes a great burden on the subjects afflicted by it. The cause for the increased burden is due to the change in lifestyle, increasing pollution index in cities that is associated with increased urbanization and presence of hazardous chemicals in air water and food.

Allergic Asthma is the most easily recognized Asthma phenotype, which often commences in childhood and is associated with a past and/or family history of Allergic disease such as Eczema, Allergic rhinitis, or food or drug Allergy (2).

\section{* Corresponding Author:}

\section{Jyotish S Jayandan}

Post Graduate Scholar, Department of Kayachikitsa,

School of Ayurveda, Amrita Vishwa Vidyapeetham,

Vallikavu, Clappana P.O, Kollam,

Kerala, India, 690525.

Email Id: jyotishjayandan@gmail.com
Prevalence of Asthma varies considerably within countries and between countries. It is more prevalent in developed countries than developing ones, more in children $(15 \%)$ than adults $(10 \%$ to $12 \%)$, more in urban than rural areas, reasons of which are not fully understood. Nearly $8 \%$ to $10 \%$ of the total world population suffers from it. In India, the prevalence of Asthma has been found to be around $7 \%$ in the majority of surveys done. However, it has been reported to vary from $2 \%$ to $17 \%$ in different study populations (3). This disease causes economic burden, hampers the quality of life, productivity, efficiency and causes work absence among subjects. As it effects mostly the younger population it effects their career and future. The current available medical management has some shortcomings and limitations (4). So, Researchers are in critical need for drugs that would minimize the disease process.

Ayurveda is a traditional medicine that is being practiced in India and now gaining popularity worldwide. Ayurvedic basic theory is moulded upon the foundation formed by the three Doshas (Biological humors) which are Vata (biological air humor), Pitta (biological fire humor) and Kapha (biological phlegm humor). The etiopathogenesis and symptoms of Allergic Asthma lies very close to the entity Tamaka Svasa (Allergic Asthma) in terms of Ayurvedic classics. Tamaka Svasa and its management has been very widely explained in classical Ayurvedic texts like Caraka Samhita, Susruta Samhita and Ashtanga Hridaya. It is a Kapha -Vata Pradhana, Pitta Sthana Samudbhavajanya Vyadhi (originating from the site of biological fire humor). Vata getting obstructed due to 
the aggravated Kapha causing its Pratiloma Gati (retrograde movement) and in turn leading to the symptoms of Tamaka Svasa. The treatments explained include Sneha (oleation), Sveda (fomentation), Vamana (drug induced vomiting), Dhupana (fumigation) in the Vegavastha (acute stage) and Virecana in the Avegavastha (in remission). The Cikitsa (treatment) which is administered should be Kapha -Vata Hara (alleviating air and fire humor), Ushna (hot in potency) and Vatanulomaka (normalising air humor) (5). So Sodhana Cikitsa (purificatory therapy) combined with Samana Cikitsa (pacificatory therapy) could be better in managing Tamaka Svasa. The literary search hinted that there are no previous published Ayurvedic works on Allergic Asthma. Clinical outcomes combined with immunological outcomes of our therapeutic protocols in Allergic Asthma has also not been evaluated. So this was an effort to analyse the effect of Sodhana Cikitsa followed by Samana Cikitsa in producing immunomodulatory (IgE) effect along with clinical outcomes in cases of Allergic Asthma.

The present study is an open label, pre and post test clinical study. 30 patients diagnosed with Allergic Asthma after considering the inclusion and exclusion criteria were included in the study. Patients who belonged to the mild and moderate overall severity of Allergic Asthma, free from attacks were included in the study. As this condition is characterised by Alpa Kapha Avastha (reduced phlegm humor), Virecana Karma is the better choice of Sodhana Karma before the administration of Samanoushadi. The patients were administered Ama Pacana (optimising digestion) with Trikatu Curnam (fine powder of dry drugs) (6) followed by Snehapana (intake of ghee in increasing quantities) with Shatpala Ghrita (medicated ghee) (7) for a maximum of 7 days followed by Sarvangha Abyangha Bhahpa Sveda (full body massage and steam bath) with Tila Taila (sesame oil) added with Saindhava Lavana (rock salt) for three days and Virecana was administered with Abhayadi Modakam (herbal purgative) (8) on the third day morning. After Samsarjana Karma (diet following purgation) patient was administered 10 grams of Citrakaharitaki Lehya (medicated linctus) (9) twice daily in divided doses as internal medicine for a period of one month.

\section{Aims \& Objectives}

- To evaluate the immunomodulatory effect (IgE) of Virecana followed by Citrakaharitaki Leha in Allergic Asthma.

- To evaluate the effect of Virecana followed by Citrakaharitaki Leha in reducing the signs and symptoms of Allergic Asthma.

- To evaluate the effect of this treatment protocol in improving Pulmonary function (P.E.F.R)

\section{Hypothesis}

- Null Hypothesis, h0- Virecana followed by Citrakaharitaki Leha is not effective in producing immunomodulatory effect (IgE) in Allergic Asthma.
- Alternate Hypothesis, h1 - Virecana followed by Citrakahareetaki Leha is effective in producing immunomodulatory effect (IgE) in Allergic Asthma

\section{Materials and Methods}

\section{Selection of Patient}

For this study 30 number of patients with classical signs and symptoms of mild to moderate Allergic Asthma free from attacks were selected based on inclusion and exclusion criteria and registered after confirming diagnosis from the OPD and IPD of Kayacikitsa (internal medicine dept) department, Amrita School of Ayurveda, Kollam, Kerala. Ethical clearance was obtained prior to the recruitment of patients.

\section{Diagnosis}

Diagnosis was confirmed through detailed history taking, clinical examinations including Respiratory assessments and supporting laboratory investigations were done in addition. After proper diagnosis case was filled up in the clinical case proforma specially designed for the present study.

\section{Inclusion Criteria}

- Either gender and age group of 20 -60 years.

- Patients having classical signs and symptoms of Allergic Asthma of mild to moderate nature coming in between attacks according to GINA 2015 criteria (10).

- Patients having raised Serum IgE levels.

- Patient fit for Snehapana, Svedana and Virecana Karma.

\section{Exclusion Criteria}

- Status Asthmaticus and Acute Asthma cases were excluded.

- Age group: less than 20 years \& exceeding 60 years are to be excluded.

- Any pre-diagnosed cases of Allergic Asthma associated with cardiovascular pathology.

- Severe Bronchial Asthma cases, Pulmonary Tuberculosis and Diabetes Mellitus.

- Pregnant Women \& lactating mothers.

- Patients with other major Lung pathologies and unfit for Snehapana and Virecana Karma.

- Discontinuation of the treatment protocol.

\section{Laboratory \& radiological investigations}

To exclude other disorders and for proper diagnosing following investigations were be done wherever necessary

- $\mathrm{Hb} \%$, TC, DC, ESR, R.B.S,

- Routine urine, Stool examination,

- Chest x ray, Mantoux test,

- E.C.G, U.S.G Abdomen.

\section{Criteria for assessment (11) \\ Subjective Criteria}

Breathlessness, Wheezing, Cough, Expectoration of sputum, Overall Severity, No of Asthma Attacks /2 weeks. 


\section{Grading of Subjective criteria (11)}

The following grading pattern was adopted.

- Breathlessness- Absent-0, Mild-1, Moderate-2, Severe-3

- Wheezing- Absent-0, Mild -1, Moderate 2, Severe -3

- Cough-Absent-0, Mild-1, Moderate-2, Severe-3

- Expectoration of sputum-Absent-0, $<2.5 \mathrm{ml} /$ day-1, $2.5-15 \mathrm{ml} /$ day-2, $15-25 \mathrm{ml} /$ day-3

- Overall Severity- Absent-0, Mild Intermittent-1, Mild Persistant-2, Moderate Persistant-3

- Number of Asthma attacks/2 weeks-Absent-0, 1-2 times-1, 3-4 times-2, 5-6 times-3

\section{Objective criteria}

- Haematological investigations

- Serum Immunoglobulin E (S. IgE)

- Absolute Eosinophil Count (AEC)

Assessment of Lung function

- Peak Expiratory Flow Rate (P.E.F.R)

Assessment of Asthma control

- Asthma Control Test (A.C.T). (10)

\section{Evaluation of overall clinical effect of therapy}

Evaluation of overall clinical effect of therapy was analysed based on the overall severity parameter before and after treatment as it includes clinical symptoms, lung function and exacerbation of Asthmatic attacks

\section{Complete therapeutic intervention}

Table 1: Complete therapeutic interventions

\begin{tabular}{|c|c|c|c|c|}
\hline S.NO & Procedure & Drug & Dose & Duration \\
\hline 1 & \multicolumn{4}{|c|}{ Pancakarma procedures (Purificatory therapy) } \\
\hline 1.1 & \multicolumn{4}{|c|}{ Purva Karma (Pre- operative procedures) } \\
\hline & Ama Pachanam & Trikatu Curnam & $\begin{array}{l}5 \text { grams twice daily before } \\
\text { food }\end{array}$ & $\begin{array}{l}\text { 4- } 5 \text { days or till the } \\
\text { appearance of Nirama } \\
\text { Lakshanas (features of } \\
\text { proper digestion) }\end{array}$ \\
\hline & Snehapanam & Shatpala Ghrita & $\begin{array}{l}\text { Ascending dose according } \\
\text { to } \mathrm{p} / \mathrm{h} \text { digestion }\end{array}$ & $\begin{array}{l}7 \text { days or till appearance } \\
\text { of Samyak Snigdha } \\
\text { Lakshanas (features of } \\
\text { proper oleation) }\end{array}$ \\
\hline & $\begin{array}{l}\text { Sarvangha Abhyangha \& } \\
\text { Bashpa Sveda }\end{array}$ & Lavanayukta Tila Tailam & 3 days & 45 minutes \\
\hline \multirow[t]{2}{*}{1.2} & \multicolumn{4}{|c|}{ Pradhana Karma ( Main purificatory therapy) } \\
\hline & Virecanam & Abhayadi Modakam & $\begin{array}{l}1-2 \text { tablets according to } \\
\text { Koshta (G.I tract) }\end{array}$ & 1 day \\
\hline \multirow[t]{2}{*}{1.3} & \multicolumn{4}{|c|}{ Paschat Karma (Post operative procedures) } \\
\hline & $\begin{array}{l}\text { Peyadi Krama (diet } \\
\text { following purgation) }\end{array}$ & & & $\begin{array}{l}\text { Acc to Sudhi (assessment } \\
\text { of purification based on } \\
\text { no of bouts of purgation) }\end{array}$ \\
\hline \multirow[t]{2}{*}{2} & \multicolumn{4}{|l|}{ Oral medications } \\
\hline & Samanoushadi & Citrakaharitaki Leha & $\begin{array}{l}5 \text { grams twice daily before } \\
\text { food }\end{array}$ & 30 days \\
\hline 3 & \multicolumn{4}{|l|}{ No: Of Patients - 30} \\
\hline \multirow[t]{3}{*}{4} & \multicolumn{4}{|l|}{ Assesment } \\
\hline & Subjective assessment & \multicolumn{3}{|l|}{ Objective assessment } \\
\hline & $\begin{array}{l}\text { - Breathlessness } \\
\text { - Wheezing } \\
\text { - Cough } \\
\text { - Sputum expectoration } \\
\text { - Overall severity } \\
\text { - No of Asthma attacks } / 2 \\
\text { weeks }\end{array}$ & \multicolumn{3}{|c|}{$\begin{array}{l}\text { - Serum IgE } \\
\text { - Absolute Eosinophil Count } \\
\text { - PEAK EXPIRATORY FLOW RATE (P.E.F.R) } \\
\text { - Asthma Control Test (A.C.T) }\end{array}$} \\
\hline
\end{tabular}

\section{Statistical Analysis}

Statistical analysis was done using SPSS VER.

20. Completed 30 patients were taken for statistical analysis. Wilcoxon signed rank test was done on subjective parameters, to interpret the time of significant change. For objective parameter Paired Samples t- Test was done for analysing the difference of significant change. 


\section{Observations}

The clinically significant observations are tabulated below.

Table 2: Showing Observations on the subjects

\begin{tabular}{l|l} 
Age - 20-29 yrs & $50 \%$ \\
\hline Religion - Hindu & $86.7 \%$ \\
\hline Occupation - Jobs other than white collar and labourers & $43.3 \%$ \\
\hline Exposure to triggering factors like dust, smoke and pollen & $46.7 \%$ \\
\hline Inhabitance - rural & $96.7 \%$ \\
\hline Appetite- regular & $73.3 \%$ \\
\hline Bowel - 1-2 times/day & $70 \%$ \\
\hline Prakruti (body type acc to Ayurveda) - Vata Kapha & $43.3 \%$
\end{tabular}

\section{Results}

Statistical significances along with the overall effect of interventions on study parameters before and after treatment are as follows.

All the subjective parameters like breathlessness, wheezing, cough, sputum expectoration, overall severity and number of Asthma attacks were highly significant $(\mathrm{p}<0.0001)$. All objective criteria's like Asthma Control Test, P.E.F.R and A.E.C were highly significant $(p<0.0001)$. Serum IgE was found to be insignificant $(p>0.05)$.

Table 3: Showing Wilcoxon signed rank test for subjective parameters

\begin{tabular}{|l|l|l|l|l|l|}
\hline Parameters & Mean Rank & Sum of Ranks & Z Value & $\boldsymbol{P}$-value & \% of relief \\
\hline Shortness of breath & 15.00 & 435.00 & -5.385 & 0.0001 & $58.00 \%$ \\
\hline Wheezing & 14.50 & 406.00 & -5.292 & 0.0001 & $62.22 \%$ \\
\hline Cough & 15.50 & 465.00 & -5.203 & 0.0001 & $73.91 \%$ \\
\hline Expectoration of sputum & 14.00 & 378.00 & -4.916 & 0.0001 & $62.00 \%$ \\
\hline Overall severity & 15.50 & 465.00 & -5.477 & 0.0001 & $56.60 \%$ \\
\hline No of Asthma attacks/2 weeks & 13.00 & 325.00 & -5.000 & 0.0001 & $56.82 \%$ \\
\hline
\end{tabular}

Table 4: Showing Paired T test on objective parameters

\begin{tabular}{|l|l|l|l|l|l|l|}
\multirow{2}{*}{ Parameter } & \multicolumn{2}{c|}{ Mean score } & \% of relief & \multicolumn{1}{|c|}{ SD } & \multicolumn{1}{c|}{ t-value } & \multicolumn{1}{c|}{$\boldsymbol{p}$-value } \\
\cline { 2 - 6 } & \multicolumn{1}{c|}{ BT } & \multicolumn{1}{c|}{ AT } & & & & \\
\hline Asthma Control Test & 17.0333 & 21.0000 & $81.12 \%$ & 1.35146 & -16.076 & 0.0001 \\
\hline PEFR & 315.6667 & 378.0000 & $83.51 \%$ & 25.00804 & -13.652 & 0.0001 \\
\hline S. IgE & 1074.3333 & 859.8333 & $19.96 \%$ & 775.05278 & 1.516 & 0.140 \\
\hline A.E.C & 577.3667 & 471.9667 & $18.25 \%$ & 124.41355 & 4.640 & 0.0001 \\
\hline
\end{tabular}

\section{Evaluation of overall clinical effect of therapy}

Evaluation of overall clinical effect of therapy was analysed based on the overall severity parameter as it includes clinical symptoms, lung function and exacerbation of Asthmatic attacks.

Before treatment out of the 30 patients included in the study 7 patients came under the severity mild intermittent in which the symptoms were very mild. persistent.

23 patients came under the severity mild

There were no patients under the severity moderate persistent.

Grading of Asthma overall severity of patients before treatment

Table 5: Showing no of patients coming under respective overall severity parameters before treatment

\begin{tabular}{|l|c|}
\multicolumn{1}{c|}{$\begin{array}{c}\text { Grade of Asthma overall } \\
\text { Severity BT }\end{array}$} & $\begin{array}{c}\text { No of patients } \\
\text { BT }\end{array}$ \\
\hline Absent & 0 \\
\hline Mild Intermittent & 7 \\
\hline Mild Persistent & 23 \\
\hline Moderate persistent & 0 \\
\hline Total & 30 \\
\hline
\end{tabular}

After treatment those 7 patients who were under the mild intermittent category were free from symptoms and the other 23 patients were relieved from mild persistent category to mild intermittent category.

\section{Grading of Asthma overall severity of patients after treatment.}

Table 6: Showing no of patients coming under respective overall severity parameters after treatment

\begin{tabular}{|l|l} 
Grade of overall severity AT & No of patients AT
\end{tabular}

Mild Intermittent relieved to absence of symptoms

Mild Persistent relieved to mild intermittent

Total

So from the above analysis suggests that 7 patients who had mild or trace, intermittent clinical presentations showed marked improvement after treatment and the rest 23 who had mild persistent clinical presentations showed moderate improvement after treatment. 


\section{Discussion}

Allergic Asthma is a clinical condition characterized by shortness of breath, wheezing, cough and or tightness of the chest. These clinical features point to the involvement of Prana Vaha Srotas (respiratory tract). Variations in the rate and pattern of breathing are indicated in Dushti (vitiation) of Prana Vaha Srotas. The clinical presentation of Allergic Asthma indicates vitiation of Vata and Kapha Doshas. The pathology involving allergy or the predisposing atopy indicate a Pitta association in this disease. The condition varies in presentations of severity, viz. mild, mild intermittent, mild persistent, moderate persistent and severe persistent. This suggests difference in Amshamsa Dosha (variation in humors) relation in each stage. Every stage will have a different proportion of Vata-Kapha involvement.

Tamaka Svasa is a variety of Svasa Roga (Asthma) with Kapha Dosha predominance. Udbhavasthana (site of origin) of this clinical condition is mentioned as Pittasthana or Adho Amasaya (duodenum). The specific Samprapti (pathogenesis) mentioned explains that there is a Pratiloma Gati of Vata by the obstructed Kapha resulting in the manifestation of this disease. Pragvata (wind) and Sleshmala Ahara (phlegm aggravating foods) may be indicators of allergens which precipitate the condition. With the above short discussion we could say that Allergic Asthma could be thought of in the lines of Tamaka Svasa in Ayurvedic literature (12).

\section{Discussion on disease}

Exposure to dust, smoke and various particulate matter was observed as the perpetuating and precipitating factors in Allergic Asthma patients of this study. Coir workers, cashew workers, salesmen etc were the study subjects. Rajas (dust) and Dhuma (smoke) exposure had been listed in the Svasa Nidana (etiology of Asthma) which initiates the disease process. It also aggravated the presenting illness. These may be the allergens that trigger the hypersensitivity type-1 reaction resulting in Asthma. The above said occupation also paved way to the constant exposure of some type of particulate matter. This also would trigger the immune mechanism ending in the disease.

All the clinical features of Allergic Asthma were present in varying severity in all individuals of the study. This indicates the inherent atopy in the individuals. The varying severity may be due to the varying levels of sensitivity to the triggering factors. Most of the patients were coming under the mild intermittent and mild persistent categories of Asthma.

The serum IgE levels varied from $259 \mathrm{IU} / \mathrm{ml}$ to $5027 \mathrm{IU} / \mathrm{ml}$ to start with. The maximum value of AEC noted in the included population was 1000 cells/cu mm. These high values are indicators of abnormal immune response. This may be due to the accumulation of Malarupa Kapha (phlegm humor in waste form) or Pitta in Rasa Dhatu (first body tissue according to Ayurveda). It could be either understood as Ama or Kledamsa (metabolic toxins/ wastes) in the circulation.
That is why the treatment started with Ama Pachana and then Kleda Nirharana (removal of metabolic wastes) through Virecana.

In this study $50 \%$ patients had episodes of running nose, sneezing, and recurrent episodes of upper respiratory tract infections prior to the manifestation of the cardinal symptoms of Asthma. $40 \%$ of the patients were having allergic symptoms since childhood and few years later they were found to have symptoms of Asthma. This shows the slow and gradual progression of type- 1 hypersensitivity towards the airways. These observations point to the relevance of past history in this clinical condition. Most of the patients reported that episodes of fever and upper respiratory tract worsened the conditions. It is in lieu to the triggering factors mentioned in the literature. Deviated nasal septum was seen in $50 \%$ of patients in this study. Jae-Cheul et al concluded that a significant association was found between obstructive nasal septum disease and asthma (13).

A Pranavaha Srotodushti Vikara with Svasa and Kasa (cough) as its main symptom is a Yapya Vyadhi (manageable). It is Sadhya (curable) if it is acute in onset. The Samprapti could be understood as;

Figure 1 - Samprapthi of Pranavaha Sroto Dushti Vikara

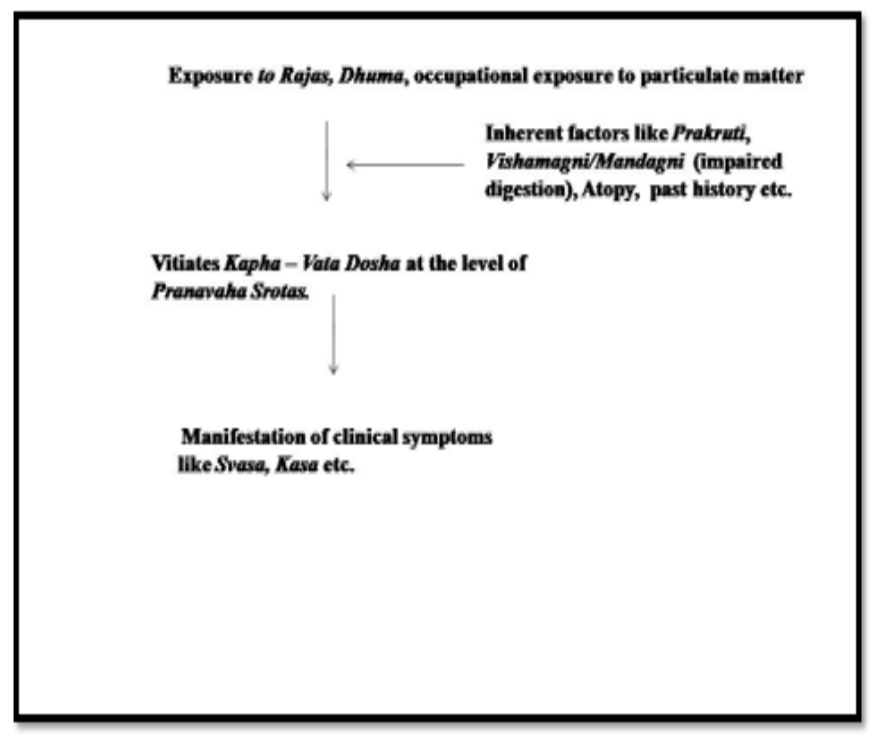

\section{Discussion on drug review}

In this study, Trikatu Curna was used for Ama Pacana, Shatpala Ghrita for Snehapana, Abhayadi Modaka for Virecana and Citrakaharitaki Leha for Vyadhi Samana.

\section{Probable mode of action of medicines Probable mode of action of Trikatu Curnam}

Mandagni and Ama formation initiates the Samprapti in Tamaka Svasa. So Trikatu Curna which contains Pippali, Marica and Nagara are given for Dipana- Pacana (optimising digestion) as the first line of management. It corrects the Agni and ensures proper Rasa Dhatu formation. Dipana drugs kindles the gastric fire but do not help in digesting the undigested food where as Pacana drugs are those which cook the 
undigested food but do not kindle the appetite. So by the combined effect of both these drugs make sure that the Ahara Paka (digestion) is proper and Sara Bhaga (essence) of Rasa Dhatu is formed properly. This reduces the over accumulation of Malarupa KaphaPitta or Kledamsa. As Tamaka Svasa is a Vata- Kapha predominant disease this will help in breaking the initial part of the basic Vyadhi Samprapti (14). Moreover Trikatu (fine powder of dried drugs) has a bioavailability enhancing action on other medicaments (15).

\section{Mode of action of Snehapana}

The mode of action of Snehapana can be explained as follows

Here Snehapana is administered as a Purvakarma of Virecana. In Tamaka Svasa the Dushti (vitiation) is at the level of Koshta. The Sneha plays an important role in Utkleshana ( excitement) of the Koshtasthita Dosha. The Snehana Karma also brings Anulomana (normalising) to the Pratiloma Vata, the major culprit in the pathogenesis (16).

\section{Mode of action of Bhashpa Svedana}

Svedana Dravya (drugs used for sudation) has its main actions like Stambhagna (removes stagnation), Gouravagna (removes heaviness), Sitagna (alleviates ailments due to cold) and Sveda Karaka (sweat inducing). The mode of action can be explained as Srotoshodhana (clearing body channels) and Vata Niyamana (normalising air-humor) - Svedana therapy induces Srotoshodhana. Proper Svedana that is administered after Snehapana helps to regulate the Vata Dosha. It is very important as Vata and Kapha are the main factors responsible for the causation of Tamaka Svasa. As a result of opening the Sveda Granthi (sweat pores) and regulating the action of Vata Dosha, stagnant Mala (metabolic wastes), Sveda and other toxins get eliminated out and Srotosudhi (clarity of channels) is attained. As in Tamaka Svasa there is Sangha (obstruction) to Vayu by the vitiated Kapha Dosha in the Srotas, this helps in bringing normal movement of Vayu in the Srotas.

Agni Dipana - Ushna and Tikshna (penetrating) properties of Svedana Karma helps in Pacana of Ama Dosha, which result in stimulation and normal functioning of Agni. It ensures that proper Paka of Ahara occurs and Dhatuparinama (bodily tissue formation) is intact. As in Tamaka Svasa there is increased production of Malarupi Kapha which is the Kitta Bhaga (waste part) of improperly formed Rasa Dhatu, for which the basic cause is Jataragni Mandyata (reduced digestion) and subsequent Ama Dosha, this Agni Dipana helps in breaking the basic Samprapti (17).

\section{Mode of action of Virecana}

Virecana is the therapeutic process by which the liquefied and Koshtagata Dosha (humors in GIT) are forcibly expelled through the anal route.

Action of Virecana Karma can be explained as follows.
In this disease where we have compared Allergic Asthma with that of Tamaka Svasa, Virecana would be working in such a way that it removes the Dushita Pitta from the Pitta Sthana and also it causes removal of the liquefied Kapha Dosha and brings Anulomana of Vata facilitating its normal functioning (18).

\section{The action of Virecana as per modern basis}

In this study Virecana was administered with Abhayadi Modakam which is basically a Stimulant purgative due to the presence of Trivrit and Danti in it. Mode of action of stimulant purgatives can be explained as follows.

\section{Stimulant Purgatives}

They are powerful purgatives: often produce gripping. They irritate the intestinal mucosa and thus stimulate motor activity. Some of them do primarily increase motility by acting on myenteric plexuses, the more important mechanism of action is accumulation of water and electrolytes in the lumen by altering absorptive and secretory activity of the mucosal cell. They inhibit $\mathrm{Na}+\mathrm{K}+\mathrm{ATP} a \mathrm{se}$ at the basolateral membrane of villous cells-transport of $\mathrm{Na}+$ and accompanying water into the interstitium is reduced. Secretion is enhanced by activation of cAMP in crypt cells and by increased PG synthesis. Larger doses of stimulant purgatives can cause excess purgation, fluid and electrolyte imbalance. Hypokalaemia can occur on regular use. Subacute or chronic intestinal obstruction is another contraindication (19).

\section{Asthma \& GERD}

GERD can be a compounding factor in the pathogenesis and development of Asthma. Not only is the asthmatic patient more likely to have GERD as compared to the general population, but also GERD is recognized as a potential trigger in many cases of severe Asthma. Several mechanisms have been implicated by which GERD may exacerbate the Asthma. Two mechanisms are important in understanding this exacerbation of Asthma.

- Oesophageal acid stimulates vagally mediated tracheobronchial responses, and this increases the bronchial hyper-responsiveness to other stimuli.

- By irritating sensitive asthmatic airways following micro-aspiration of even tiny refluxed material into the tracheobronchial tree, which contributes to the adverse airway effects.

So it can be understood that Virecana helps in removing the excess oesophageal acid reflux thereby reducing chances for Asthma excaberation due to acid reflux as it works mainly on Pitta Dosha and at the Pitta Sthana (20).

\section{Mode of action of Citrakaharitaki Lehya}

Citrakaharitaki Leha - The pharmacological properties of Citrakaharitaki Leha are as follows:

Katu, Tikta Rasa (bitter and pungent in taste) predominant; Laghu, Ushna, Ruksha Guna (light, hot and dry by nature) predominant; Ushna Virya (hot in 
potency) predominant; Katu Vipaka (metabolic endproduct is pungent) predominant and Dosha Karma of the drugs are Vata Kapha Hara in nature.

The properties of drugs and medicaments used in Tamaka Svasa are explained to be as KaphaVatagna, Ushna and Vatanulomana in nature.

So when Citrakaharitaki is given as a postVirecana Samanoushadi it works at multiple levels to break the basic Samprapti.

- Agni Dipana- Ushna Guna does Agni Dipana making sure that Ahara Parinama is proper

- Dosha Samana - Ushna Virya acts against both Vata and Kapha Dosha as they are (humors cold in nature)

- Anulomana to Vata Dosha.

- By these actions it helps in reversing the basic Samprapti of the disease (21).

\section{The action of Citrakaharitaki Leha as per modern basis}

Pharmacological studies of the ingredients of Citrakahariaki Leha reveals that Citraka, Haritaki, Amalaki, Guduci, Syonaka, Agnimantha, Gokshura, Gambhari, Prisniparni, Pippali, Nagara, Maricha and Patra are having Immonomodulatory Actions. Anti inflammatory activity is possessed by Citraka, Amalaki, Syonaka, Agnimantha, Gokshura, Gambhari, Prisniparni, Pippali, Nagara, Maricha, Patra and Tvak. Citraka is anti allergic and Ela has Broncho dilatory activity.

So it could be by the virtue of these pharmacological properties, Citrakaharitaki Leha works as an Anti- Asthmatic, Anti-Allergic and immunomodulatory agent (21).

\section{Discussion on observation}

- Age-Among the 30 patients maximum number of patients i.e. $50 \%$ belonged to age group of 20-29 years and $13.3 \%$ belonged to $30-39$ years of age group. The high number of observations in this group may be due to the physiological predominance of Kapha Dosha in this age group. Maximum incidence was found in women and in the age group 20-29.

- Religion: The maximum number of patients i.e. 86.7 $\%$ were Hindus, followed by $10 \%$ were Muslims and rest $3.3 \%$ patients were Christians. This may due to the predominance of Hindu population in this locality.

- Occupational status of subject: Maximum number of patients i.e. $40 \%$ were having white collar jobs, followed by $16.7 \%$ patients were labourers, and 43.3 $\%$ patients were having other jobs. The higher observation noted may be due to the exposure to allergens.

- Exposure to triggering factors: The maximum number of patients i.e. $46.7 \%$ were having exposure to dust, pollen and smoke, followed by $33.3 \%$ patients were exposed to cold climate, $16.7 \%$ patients were prone to travelling and $3.3 \%$ patients were having exposure to hazardous chemicals. Exposure to aluminium roofing work was observed to be a triggering factor. Exposure to acacia tree is also found to be a major cause for the causation of type 1 hypersensitivity.
- Inhabitance: Among the 30 patients maximum number of patients i.e. $96.7 \%$ were of rural inhabitance and $3.3 \%$ patients were of urban inhabitance. It could be due to the reason that the hospital is located at a rural area.

- Diet: The maximum number of patients i.e. $90 \%$ were taking mixed diet, and rest $10 \%$ patients were vegetarians. Crustaceans like prawns and shellfish can initiate type 1 hypersensitivity.

- Appetite: The maximum numbers of patients i.e. 73.3 $\%$ were having regular appetite and rest $26.7 \%$ patients were having irregular appetite.

- Bowel: The maximum number of patients i.e. $70 \%$ were having 1-2 times of bowel movement followed by $20 \%$ patients were having constipated bowels and rest 10\% were having 2-3 times of bowel movement.

- Prakriti: The maximum number of patients i.e. 43.3 \% were having Vata Kapha Prakriti followed by 30 $\%$ patients were having Pitta Kapha Prakriti and rest $26.7 \%$ were having Vata Pitta Prakriti. Higher observation noted in Vata-Kapha Prakriti may be due to the Tulyata (similarity) of Dosha Avastha in Tamaka Svasa.

\section{Discussion on effect of therapies}

\section{Effect of therapy on subjective parameters}

- Effect on shortness of breath- There was a relief of $58 \%$ in shortness of breath after treatment. It was found to be significant at $(\mathrm{P}$ value $<0.0001)$. It could be due to that fact that after Virecana and Samanoushadi, the airway hyperresponsiveness to allergens could have reduced probably thereby preventing microvascular leakage, inflammation and subsequent bronchoconstriction which leads to shortness of breath.

- Effect on wheezing- There was a relief of $62.22 \%$ in wheezing after treatment. It was found to be significant at $(\mathrm{P}$ value $<0.0001)$. It could be due to the same mechanism explained for shortness of breath that after Virecana and Samanoushadi the airway hyperresponsiveness to allergens could have reduced probably thereby preventing microvascular leakage, inflammation and subsequent bronchoconstriction which leads to narrowing of airways which cause wheezing.

- Effect on cough- There was a relief of $73.91 \%$ in cough after treatment. It was found to be significant at ( $\mathrm{P}$ value $<0.0001)$. Most of the patients included in this study were having mild scores of cough and the treatment would have brought mucolysis in the airways resulting in reduction of cough which is a reflux mechanism to remove the mucous secretions which could be the probable cause for the relief.

- Effect on expectoration of sputum- There was a relief of $62.0 \%$ in expectoration of sputum after treatment. It was found to be significant at ( $\mathrm{P}$ value $<$ 0.0001). It could be due to the same mechanism explained for cough that Virecana and Samanoushadi would have brought mucolysis in the airways resulting in reduction of sputum expectoration. 
- Effect on number of Asthma attacks- There was a relief of $56.82 \%$ in number of asthmatic attacks after treatment. It was found to be significant at $(\mathrm{P}$ value $<$ $0.0001)$. It could be due to that fact that after Virecana and Samanoushadi the airway hyperresponsiveness to allergens could have reduced probably thereby preventing chances of initiating a type 1 hypersensitivity reaction which is the prime initiator of an Asthmatic attack thereby reducing the number of Asthma Attacks in total.

\section{Effect of therapy on objective parameters}

- Effect on Asthma Control Test- There was a relief of $81.12 \%$ in Asthma control test after treatment. It was found to be significant at ( $\mathrm{P}$ value $<0.0001)$. As there is reduction in number of Asthma attacks, increase in quality of life, reduced work absence, Asthma Control Test rises automatically.

- Effect on Peak Expiratory Flow Rate (P.E.F.R) There was a relief of $83.51 \%$ in P.E.F.R after treatment. It was found to be significant at $(\mathrm{P}$ value $<$ $0.0001)$. It could be due to that fact that after Virecana and Samanoushadi the airway mucous hypersecretion and oedema should have reduced probably and there could be minimal dilatation of airways thereby increasing air intake and Lung function.

- Effect on serum Immunoglobulin E- There was $19.96 \%$ relief in serum IgE. But there was no statistically significant difference between the mean IgE before treatment and after treatment $(\mathrm{P}$ value $>$ $0.05)$. IgE levels were reducing but not up to a significant level. The probable cause could be the short time period of intake of post Virecana Samanoushadi and less number of medicines post Virecana. It can be inferred that the allergic immunoglobulin could be taking more time for its reduction in serum and also a minor exposure to the triggering factors could have contributed to its rise in serum.

- Effect on Absolute Eosinophil Count (AEC)-There was a relief of $18.25 \%$ in AEC after treatment. It was found to be significant at $(\mathrm{P}$ value $<0.0001)$. Eosinophils being a major inflammatory cell in Allergic Asthma as there is reduced action of pre inflammatory mediators, the eosinophil infiltration could have reduced after the whole treatment protocol.

\section{Conclusion}

So based on the observations and critical analysis following conclusions have been derived.

- Patients of Allergic Asthma coming under the mild to moderate category can be compared to that of Tamaka Svasa on basis of clinical presentation and can be managed on the lines of Tamaka Svasa Cikitsa explained in Ayurvedic Texts.

- Virecana followed by Citrakaharitaki Leha was found to be significant in producing clinical outcomes and increasing P.E.F.R.

- Virecana followed by Citrakaharitaki Leha was found to be not significant in producing immunomodulatory effect (IgE) in Allergic Asthma.
- Thus based on the observations made in the clinical study the alternate hypothesis is rejected and null hypothesis is accepted i.e. Virecana followed by Citrakaharitaki Leha is not effecting in producing immunomodulatory effect in Allergic Asthma.

\section{Limitations and recommendations}

Compact and final conclusions cannot be made due to small sample size and the short study period.

Follow up was not done and the post treatment status of the patients could not be assessed with regards to the sustained relief.

The study can be repeated with a larger sample size and longer study duration

As Kapha Dosha is one of the main culprit behind the pathogenesis of the disease, its Visishta Cikitsa (specific treatment) ie, Vamana Karma can be administered prior to Virecana to evaluate whether the results are better when compared to Virecana alone.

The reason for insignificant immunological outcomes could be due to the lesser duration of treatment protocol and less number of medicines post Virecana. If there were more Samanoushadis after treatment the results would have been better.

More studies should be done to evaluate the effect of other Ayurvedic treatments at the Immune levels with the help of more parameters.

\section{References}

1. Rajendra Prasad, Raj Kumar, Allergy Situation in India: What is Being Done. Editorial, Indian J. Chest Dis. Allied Sci. 2013; 55; 7-8.

2. http://ginasthma.org/wp. dated 22-03-2018 time 10.30 IST.

3. Virendra Singh, Ajeet Singh. API Textbook of Medicine. 9th ed. New Delhi; Jaypee Brothers Medical Publishers; 2012.1704p.

4. Virendra Singh, Ajeet Singh. API Textbook of Medicine. 9th ed. New Delhi; Jaypee Brothers Medical Publishers; 2012.1709p.

5. Sharma R K, Bhagwan Dash. Caraka Samhita of Agnivesha, Chikitsa Sthana. Ch. 17, Ver. 147-150. Reprint ed. Varanasi; Chowkambha Sanskrit Series Office; 2009. 153p.

6. Sreekumar T. Ashtanga Hridaya of Vagbhatta, Sutrasthana. Ch. 06, Ver. 165-166. 2nd ed. Thrissur; Publication dept, Harisri hospital; 2008. 208 p.

7. Srikantamurthi K.R. Ashtanga Hridaya of Vagbhatta, Chikitsasthana. Ch. 05, Ver. 22-23. 1st ed. Varanasi; Krishnadas Academy; 1992. 258-9p.

8. Srikantamurthi K.R. Sarngadhara Samhita of Sarngadhara, Uthara Khanda. Ch. 04, Ver. 26-33. $4^{\text {th }}$ ed. Varanasi; Chowkamba Orientalia; 2001. $206 p$.

9. Kanjiv Lonchan. Bhaishajya Ratnavaly of Govind Das Sen, Ch. 63, Ver. 31-33. 17th ed. Varanasi; Chowkamba Sanskrit Samsthn; 2004. 687p.

10. http://ginasthma.org/wp-content/uploads/2016/01/ GINA_Report_2015_Aug11-1.pdf. dated 22-03-2018 time $\overline{10}$.50 IST.

11. Shyam Prasad M, Evaluation of the role of Nithyavirechana and Nayopayam kashaya in 
Tamaka Shwasa. Ayu. 2010; 31(3); 294-299. Available from https://www.ncbi.nlm.nih.gov/pmc/ articles/PMC3221061/

12. Sharma R K, Bhagwan Dash. Caraka Samhita of Agnivesha, Chikitsa Sthana. Ch. 17, Ver. 55-62. Reprint ed. Varanasi; Chowkambha Sanskrit Series Office; 2009. 131-132p.

13. Ahn Jae- Cheul, Nasal Septal Deviation With Obstructive Symptoms: Association Found With Asthma but Not With Other General Health Problems. Am J Rhinol Allergy. March, 2016; $30(2) ; 17-20$. Available from https:// pubmed.ncbi.nlm.nih.gov/26980380/ \#: :text=A\%20significant $\% 20$ association $\% 20 \mathrm{was} \%$ 20 found, $\mathrm{a} \% 20$ chronic $\% 20$ nasal $\% 20$ obstructive $\% 20$ symptom.

14. Srikantamurthi K.R. Sarngadhara Samhita of Sarngadhara, Prathama Khanda. Ch. 04, Ver. 1-2. $4^{\text {th }}$ ed. Varanasi; Chowkamba Orientalia; 2001. 17p.

15. Johri R.K, An Ayurvedic Formulation 'Trikatu' and Its Constituents. J Ethnopharmacol. Sep, 1992; 7(2);85-91. Available from https:// pubmed.ncbi.nlm.nih.gov/1434692/
16. Vasanth C Patil. Principles and Practice of Pancakarma. 2nd ed. Ilkal (Karnataka); Atreya Ayurvedic Publications; 2011.177-179p.

17. Vasanth C Patil. Principles and Practice of Pancakarma. $2^{\text {nd }}$ ed. Ilkal (Karnataka); Atreya Ayurvedic Publications; 2011. 239-241p.

18. Vasanth C Patil. Principles and Practice of Pancakarma. 2nd ed. Ilkal (Karnataka); Atreya Ayurvedic Publications; 2011. 379-382p.

19. Tripathi K. D. Essentials of Medical Pharmacology. $6^{\text {th }}$ ed. New Delhi; Jaypee Brothers Medical Publishers; 2008. 653p.

20. Gaude Gajanan S, Pulmonary manifestations of gastroesophageal reflux disease. Ann Thorac Med. Jul, 2009; 4(3); 115-123. Available from http:// www.thoracicmedicine.org/article.asp? issn $=1817-1737$; year $=2009$; volume $=4$; issue $=3$; spag $\mathrm{e}=115$; epage $=123$; aulast $=$ Gaude.

21. Jyotish S Jayandan, A review on Immunomodulation and Immunoprotection in Allergic Asthma: An Ayurvedic approach. Int J Res in Ayurveda. Phar. 2017; 8(2): 73-77. Available from http://ijrap.net/admin/php/uploads/ 1774 pdf.pdf. 